\title{
PERANCANGAN PERANGKAT LUNAK PENDUKUNG ETC (ELECTRONIC TOLL COLLECTION) DENGAN NOTIFIKASI MELALUI SOCIAL MESSENGER
}

\author{
Yusuf Baharuddin*), Aghus Sofwan, dan Wahyul Amien Syafei \\ Departemen Teknik Elektro, Universitas Diponegoro \\ Jl. Prof. Sudharto, SH, Kampus UNDIP Tembalang, Semarang 50275, Indonesia \\ ${ }^{*}$ E-mail: baharuddinucup@gmail.com
}

\begin{abstract}
Abstrak
Kemacetan yang terjadi di gerbang tol disebabkan oleh volume kendaraan yang melebihi kapasitas layanan gerbang tol. Salah satu teknologi untuk meningkatkan laju pelayanan pada gerbang tol adalah ETC (Electronic Toll Collection). ETC yang dikembangkan saat ini dapat memberikan notifikasi melalui SMS, tetapi biaya untuk mengirim SMS masih terbilang mahal. Penelitian ini mengusulkan solusi dengan menggunakan notifikasi melalui social messenger yang menggunakan internet yang lebih murah daripada SMS. Mobil yang terpasang OBU melewati gerbang tol dideteksi oleh OBU reader dan datanya dikirim ke cloud. Cloud mengirimkan data ke pengendara via social messenger. Data ini mejadi bukti pembayaran yang sah. Hasil pengujian sistem, notifikasi pembayaran dikirimkan via social messenger bekerja pada jaringan $2 \mathrm{G}$, 3G, dan 4G dengan rata-rata waktu respon masing-masing jaringan adalah 5,24 detik, 4,99 detik, dan 4,05 detik. Jumlah pengguna kurang dari sama dengan 30, social messenger dapat mengirim notif dengan waktu kurang dari 1,7 detik.
\end{abstract}

Kata kunci: Social Messenger, perangkat bergerak, sistem bot, ETC

\begin{abstract}
The Traffics occur at the toll gate caused by the volume of vehicles that exceed the capacity of the service to toll gate. One of the technologies to increase the rate of service on toll gate is the ETC (Electronic Toll Collection). ETC are being developed at this time can give you a notification via SMS, but the cost to send an SMS is still relatively expensive. This thesis proposes solutions using notification via social messenger who use the internet are cheaper than SMS. The car's built-in OBU passing toll Gates detected by the OBU reader and data sent to the cloud. Cloud Rider to send the data via social messenger. These data become a valid proof of payment. The results of the testing system of payment, a notification is sent via social messenger works on $2 \mathrm{~g}, 3 \mathrm{~g}$, and $4 \mathrm{~g}$ with an average response time of each network is 5.24 seconds, 4.05 seconds, and 4.99 seconds. The number of users is less than equal to 30 , social messenger can send notif with less than 1.7 seconds.
\end{abstract}

Keywords : Social Messenger, mobile device, bot system, ETC

\section{Pendahuluan}

Dewasa ini jumlah pengguna jalan baik dari motor maupun mobil meningkat pesat. Tak jarang ditemui kemacetan di beberapa daerah. Upaya-upaya sudah dilakukan oleh pemerintah untuk mengatasi kemacetan ini. Salah satunya dengan membangun jalan tol atau jalan bebas hambatan. Hambatan yang dimaksud adalah kemacetan yang terjadi pada jalan-jalan biasa yang dilewati oleh berbagai jenis kendaraan. Diharapkan adanya jalan tol ini, para pengguna jalan tol dapat merasakan nyaman karena tidak adanya kemacetan jika melalui jalan tol dan dapat lebih cepat sampai ketujuan karena tidak terjebak macet.
Di Indonesia, sudah menerapkan gerbang tol elektronik yaitu GTO (Gerbang Tol Otomatis). GTO dalam perkembangan masih menggunakan smart card untuk proses identifikasi. Proses ini mengharuskan para pengendara kontak dengan reader smart card yaitu menempelkan kartu ID pada reader smart card. Dan bukti pembayaran yang masih konvensional yaitu dengan memberikan struk pembayaran berbentuk kertas kecil sehingga pengendara harus mengambil struk tersebut. Proses ini menjadi penyebab aliran di gerbang tol yang menjadi lama. Ditambah lagi, kenyataannya struk tersebut akan dibuang dan tidak terpakai lagi. Struk ini akan mengakibatkan kotor pada jalan tol ataupun pada gerbang tol [1]. 
Dengan memanfaatkan teknologi non kontak yang biasa disebut dengan Radio Frequency Indentification (RFID), diharapkan dapat meningkatkan pelayanan di gerbang tol [3][4][5]. RFID dapat mendeteksi sebuah kendaraan dari jarak jauh dan tanpa adanya kontak langsung karena RFID menggunakan detektor jarak jauh. Sistem identifikasi kendaraan sudah terjadi sebelum kendaraan melewati gerbang tol, sehingga para pengendara tidak akan berhenti untuk melakukan pembayaran ataupun mengambil struk pembayaran. Pengendara yang telah melewati gerbang tol dapat mengurangi waktu terbuang yang ada di gerbang tol.

ETC (Electronic Toll Collection) yang dikembangkan saat ini juga dapat memberikan notifikasi melalui SMS [2], sehingga dapat menghilangkan penggunaan kertas yang akan berdampak pada berkurangnya pengotoran lingkungan. Namun, biaya untuk mengirim SMS masih terbilang mahal. Solusi untuk ini adalah dengan menggunakan notifikasi melalui social messenger yang menggunakan paket data internet yang lebih murah daripada SMS. Notifikasi melalui social messenger ini menjadi bukti pembayaran sah karena terjadi transaksi antara pengguna dan pihak PT. Jasa Marga. Dari latar belakang ini, maka dibuat penelitian tentang perancangan Gerbang Tol Pintar berbasis RFID dengan notifikasi pembayaran via social messenger, yang akan berdampak pada pengurangan waktu yang dibutuhkan untuk transaksi masuk jalan tol dan pengurangan biaya operasional dengan menggunakan social messenger untuk mengirimkan bukti pembayaran.

Penelitian ini bertujuan untuk merancang perangkat lunak Pendukung ETC (Electronic Toll Collection) dengan notifikasi melalui social messenger yaitu Telegram dengan menggunakan bot yang dimiliki Telegram. Aplikasi ini dapat memberikan notifikasi pembayaran tol setelah kendaraan masuk dalam gerbang tol yang menggunakan sistem ETC.

\section{Metode}

\subsection{Webhook}

Dengan Webhook, aplikasi dapat menerima pemberitahuan ketika terdapat perubahan terhadap serangkaian topik yang dipilih beserta kolomnya. Misalnya, mengatur webhook untuk topik User dan berlangganan ke kolom email, serta akan diberi tahu ketika pengguna memperbarui alamat emailnya. Hal ini mencegah agar tidak bergantung pada permintaan API berkelanjutan atau bahkan periodik untuk memeriksa pembaruan yang mungkin atau tidak mungkin terjadi. Hal ini juga membantu untuk menghindari pembatasan laju.

Pemberitahuan pembaruan webhook dikirimkan sebagai permintaan POST ke URL callback yang diberikan. Pemberitahuan dapat berupa hal yang sederhana, hanya mengindikasikan bahwa sebuah kolom sudah diperbarui, atau dapat menyertakan nilai yang baru diperbarui.
Webhook merupakan salah satu metode mengambil pesan pada Telegram. Gambar 1 menggambarkan cara kerja bot menggunakan metode webhook.

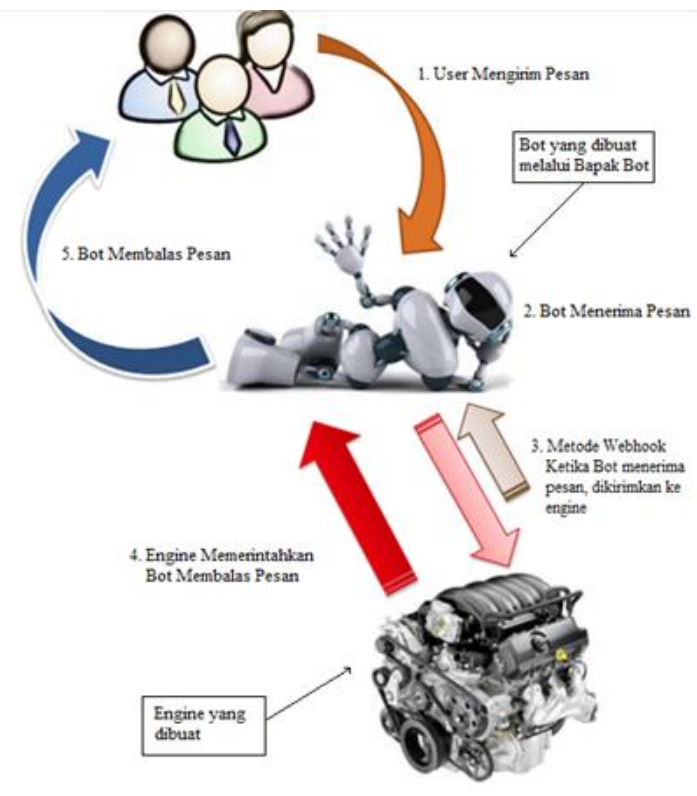

Gambar 1. Cara Kerja Bot

\subsection{Model-View-Controller (MVC)}

MVC (Model View Controller) adalah konsep dasar yang harus diketahui sebelum mengenal CodeIgniter. MVC adalah sebuah pattern/teknik pemrograman yang memisahkan bisnis logic (alur pikir), data logic (penyimpanan data) dan presentation logic (tampilan aplikasi) atau secara sederhana adalah memisahkan antara desain, data dan proses [6]. Adapun komponen-komponen MVC antara lain :

\subsubsection{Model}

Model berhubungan dengan data dan interaksi ke database atau web service. Model juga mempresentasikan struktur data dari aplikasi yang bisa berupa database maupun data lain, misalnya dalam bentuk file teks, file XML, maupun webservice. Model berisi class dan fungsi untuk mengambil, melakukan update dan menghapus data website. Sebuah aplikasi web biasanya menggunakan database dalam menyimpan data, maka pada bagian model biasanya berhubungan dengan perintah-perintah query SQL.

\subsubsection{View}

View berhubungan dengan segala sesuatu yang ditampilkan ke end-user. Bisa berupa halaman web, RSS, JavaScript dan lain-lain. Programmer menghindari adanya logika atau pemrosesan data di view. Di dalam view hanya berisi variabel-variabel yang berisi data yang ditampilkan. View dapat dikatakan sebagai halaman website yang dibuat 
dengan menggunakan HTML dan bantuan CSS atau JavaScript. Di dalam view tidak diperbolehkan ada kode untuk melakukan koneksi ke database. View hanya dikhususkan untuk menampilkan data-data dari model atau controller.

\subsubsection{Controller}

Controller bertindak sebagai penghubung data dan view. Di dalam controller inilah terdapat class-class dan fungsifungsi yang memproses permintaan dari view ke dalam struktur data di dalam model. Controller juga tidak berisi kode untuk mengakses database karena tugas mengakses data telah diserahkan kepada model. Tugas controller adalah menyediakan berbagai variabel yang akan ditampilkan di view, memanggil model untuk melakukan akses ke database, menyediakan penanganan kesalahan/error, mengerjakan proses logika dari aplikasi serta melakukan validasi atau cek terhadap input.

Pada eksekusi PHP biasanya programmer akan me-load semua library dan fungsi yang dibutuhkan kemudian digabungkan ke dalam HTML untuk di eksekusi oleh PHP. Untuk kasus sederhana cara tersebut masih baik-baik saja, tetapi ketika aplikasi tersebut menjadi komplek/rumit maka kita akan sulit memeliharanya jika tidak didukung oleh arsitektur software yang bagus. Hal tersebut bisa terjadi disebabkan oleh kode yang sama namun dibuat berulang-ulang, kode tidak konsisten dan lain-lain. Sedangkan CodeIgniter menggunakan pola MVC, dipetakan menjadi model, view dan controller. Pola MVC dapat dilihat pada Gambar 2.

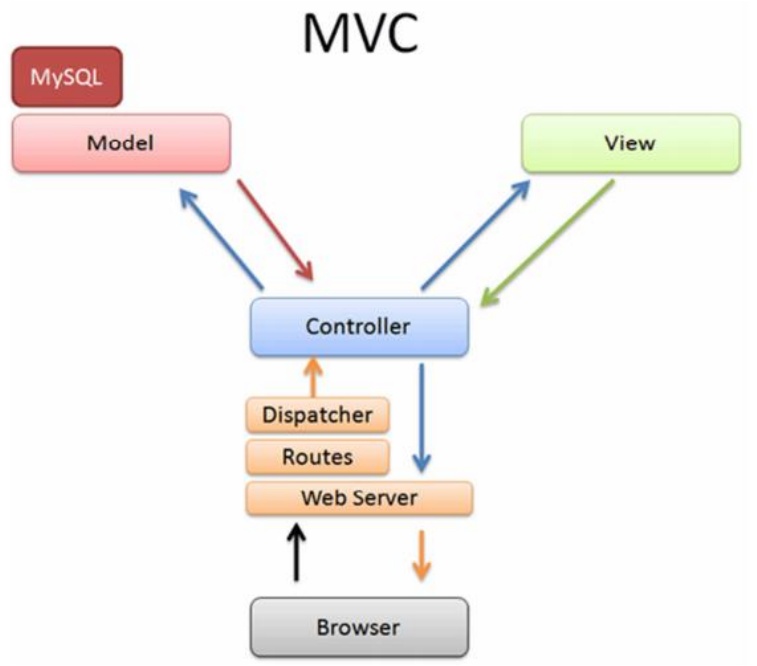

Gambar 2. Flow CodeIgniter

Jika dipetakan, alur kerja CodeIgniter digambarkan pada Gambar 2 browser berinteraksi melalui controller. Controller-lah yang menerima dan membalas semua request dari browser. Untuk data maka controller meminta ke model dan untuk UI/template meminta ke view. Jadi "otak" dari aplikasi ada di controller, "muka" aplikasi ada di view dan "data" aplikasi ada di model. Ketika browser meminta sebuah halaman web maka router mencarikan controller mana yang harus menangani request tersebut. Controller menggunakan model untuk mengakses data dan view untuk menampilkan data tersebut.

\subsection{Diagram Use Case}

Diagram use case menggambarkan fungsi-fungsi yang ada pada sistem [7]. Diagram ini lebih berfokus pada fitur-fitur sistem dari sudut pandang pihak luar, yang dalam hal ini adalah user aplikasi baik admin yang mengelola web dan pelanggan yang mengggunakan Telegram. Diagram use case untuk perancangan sistem yang dibuat terdiri dari diagram use case untuk web dan diagram use case untuk pelanggan. Diagramnya dapat dilihat pada Gambar 3 dan Gambar 4.

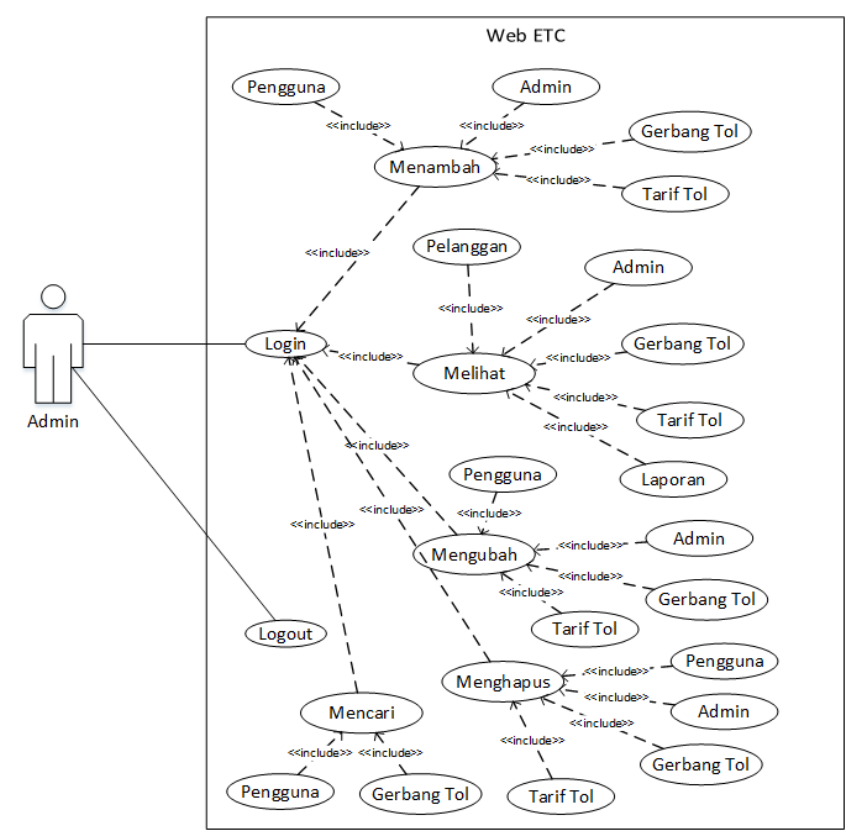

Gambar 3. Diagram Use Case Web

Gambar 3 menggambarkan fitur-fitur yang dapat diakses oleh admin. Admin dapat mengakses semua menu yang teradapat dalam web ETC ini. Pertama yang harus dilakukan adalah login, setelah itu admin dapat menambah, melihat, mengubah, menghapus dan mencari. Jika admin ingin keluar dari web, menekan tombol logout.

Gambar 4 menggambarkan fitur-fitur yang dapat diakses oleh pelanggan ketika dia menggunakan bot telegram. Pelanggan dapat mengakses semua fitur yang teradapat dalam bot telegram ini. Agar dapat menggunakan semuanya pelanggan harus menambah bot terlebih dahulu. Selanjutnya, adalah memverifikasi nomor telepon. Jika tidak demikian, maka pelanggan tidak dapat mengetahui saldo maupun transaksi saldo karena pelanggan belum terkoneksi dengan database. 


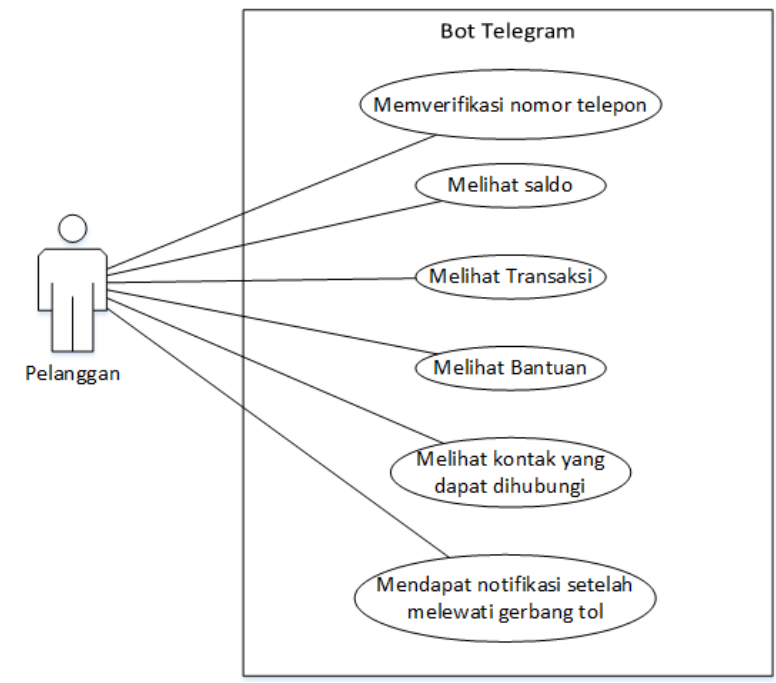

Gambar 4. Diagram Use Case Pelanggan

\subsection{Relasi Database}

Rrelasi database menggambarkan hubungan antar tabel pada database. Bertujuan untuk memberikan gambaran database pada sistem yang dibuat. Diagram relasional database ini dapat dilihat pada Gambar 3.

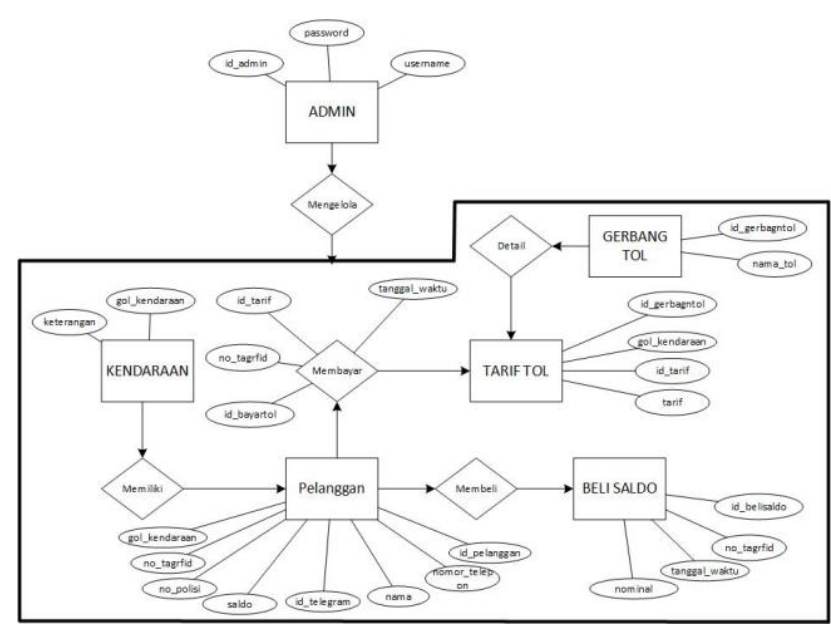

\section{Gambar 5. Diagram Relasional Database}

Gambar 5 menggambarkan hubungan antar tabel pada sistem yang dibuat. Dari gambar 3 entitas atau tabel pada database meliputi admin, kendaraan, pelanggan, tarif tol, gerbang tol dan beli saldo. Relasi membayar menjadi suatu tabel tersendiri karena memiliki atribut sendiri. Atribut pada tabel kendaraan yaitu gol_kendaraan dan keterangan. Atribut pada tabel pelanggan yaitu no_tagrfid, nama, nomor_telepon, id_telegram, no_polisi, gol_kendaraan, dan saldo. Atribut pada tabel beli saldo yaitu id_belisaldo, no_tagrfid, tanggal_waktu, dan nominal. Atribut pada tabel tarif tol yaitu id_tarif, id_gerbangtol, gol_kendaraan, dan tarif. Atribut pada tabel gerbang tol yaitu id_gerbangtol dan nama_tol. Atribut pada tabel membayar yang dimaksud adalah membayar tol yaitu id_bayartol, no_tagrfid, tanggal_waktu, dan id_tarif.

\section{Hasil \& Analisa \\ 3.1. Pengujian Fungsi Sistem Berdasarkan Berbagai Browser Desktop}

Pengujian fungsi sistem dilakukan dengan membuka halaman yang memuat fungsi dan melakukan simulasi menjalankan sistem. Untuk pengujian, telah dipilih empat browser sebagai pembanding kerja fungsi sistem. Hasil pengujian fungsi sistem berdasarkan berbagai browser desktop dimuat pada Tabel 1.

Tabel 1. Hasil Pengujian Berbagai Browser Desktop

\begin{tabular}{|c|c|c|c|c|}
\hline \multirow[b]{2}{*}{ Fungsi Sistem } & \multicolumn{4}{|c|}{ Browser } \\
\hline & $\begin{array}{c}\text { Google } \\
\text { Chrome } \\
61\end{array}$ & $\begin{array}{c}\text { Ms } \\
\text { Edge } \\
40 \\
\end{array}$ & $\begin{array}{c}\text { Mozilla } \\
\text { Firefox } \\
56\end{array}$ & $\begin{array}{c}\text { UC } \\
\text { Browser } 7\end{array}$ \\
\hline Login & berhasil & berhasil & berhasil & berhasil \\
\hline $\begin{array}{l}\text { Melihat halaman } \\
\text { beranda }\end{array}$ & berhasil & berhasil & berhasil & berhasil \\
\hline Melihat data pengguna & berhasil & berhasil & berhasil & berhasil \\
\hline Melihat data gerbang tol & berhasil & berhasil & berhasil & berhasil \\
\hline Melihat data tarif tol & berhasil & berhasil & berhasil & berhasil \\
\hline $\begin{array}{l}\text { Melihat data golongan } \\
\text { kendaraan }\end{array}$ & berhasil & berhasil & berhasil & berhasil \\
\hline Melihat data admin & berhasil & berhasil & berhasil & berhasil \\
\hline $\begin{array}{l}\text { Melihat laporan } \\
\text { pembayaran tol }\end{array}$ & berhasil & berhasil & berhasil & berhasil \\
\hline $\begin{array}{l}\text { Melihat laporan } \\
\text { pembelian saldo }\end{array}$ & berhasil & berhasil & berhasil & berhasil \\
\hline $\begin{array}{l}\text { Menambahkan } \\
\text { pengguna }\end{array}$ & berhasil & berhasil & berhasil & berhasil \\
\hline $\begin{array}{l}\text { Menambahkan gerbang } \\
\text { tol }\end{array}$ & berhasil & berhasil & berhasil & berhasil \\
\hline Menambahkan tarif tol & berhasil & berhasil & berhasil & berhasil \\
\hline Menambahkan admin & berhasil & berhasil & berhasil & berhasil \\
\hline Mengubah pengguna & berhasil & berhasil & berhasil & berhasil \\
\hline Mengubah gerbang tol & berhasil & berhasil & berhasil & berhasil \\
\hline Mengubah tarif tol & berhasil & berhasil & berhasil & berhasil \\
\hline Mengubah admin & berhasil & berhasil & berhasil & berhasil \\
\hline Menghapus pengguna & berhasil & berhasil & berhasil & berhasil \\
\hline Menghapus gerbang tol & berhasil & berhasil & berhasil & berhasil \\
\hline Menghapus tarif tol & berhasil & berhasil & berhasil & berhasil \\
\hline Menghapus admin & berhasil & berhasil & berhasil & berhasil \\
\hline Mencari data pengguna & berhasil & berhasil & berhasil & berhasil \\
\hline $\begin{array}{l}\text { Mencari data gerbang } \\
\text { tol }\end{array}$ & berhasil & berhasil & berhasil & berhasil \\
\hline Logout & berhasil & berhasil & berhasil & berhasil \\
\hline
\end{tabular}

Seluruh browser bekerja dengan berhasil. Dapat ditarik hasil akhir bahwa sistem bekerja dengan baik dimana tingkat keberhasilannya mencapai $100 \%$. Browser yang dipilih untuk pengujian adalah yang mendukung Css dan Javascript. Maka dari itu, dilakukan pengujian untuk mempertimbangkan kualitas browser yang digunakan. Pengujian kualitas browser dilakukan melalui dua alamat web. Pertama untuk kualitas halaman, pada html5test.com dengan nilai maksimal 555. Kedua untuk kualitas style halaman, pada css3test.com engan nilai maksimal 1802 . Tabel 2 menunjukkan pengujian kehandalan browser melalui dua alamat web tersebut. 
TRANSIENT, VOL. 7, NO. 1, MARET 2018, ISSN: 2302-9927, 59

Tabel 2. Hasil Pengujian Kehandalan Browser

\begin{tabular}{ccccc}
\hline Web Pengujian & $\begin{array}{c}\text { Google } \\
\text { Chrome } \\
61\end{array}$ & $\begin{array}{c}\text { Ms } \\
\text { Edge 40 }\end{array}$ & $\begin{array}{c}\text { Mozilla } \\
\text { Firefox } \\
\mathbf{5 6}\end{array}$ & $\begin{array}{c}\text { UC } \\
\text { Browser 7 }\end{array}$ \\
\hline $\begin{array}{c}\text { html5test.com } \\
\text { (maksimum }=555) \\
\text { css3test.com } \\
\text { (maksimum }= \\
\text { 1802) }\end{array}$ & 518 & 468 & 478 & 492 \\
\hline
\end{tabular}

Hasil pengujian pemuatan halaman, melalui alamat html5test.com, menunjukkan browser dengan kualitas terendah adalah Ms Edge. Browser tersebut dapat memuat semua fungsi halaman sistem secara sukses $100 \%$. Dapat disimpulkan bahwa meskipun dimuat pada browser kualitas rendah, sistem dapat bekerja dengan baik.

Hasil pengujian pemuatan style halaman, melalui css3test.com, menunjukkan bahwa browser Ms Edge memiliki kualitas terendah di antara browser lain. Merujuk dari Tabel 1, menyatakan semua fungsi sistem yang dimuat browser Ms Edge menunjukkan hasil sukses. Maka, dapat ditarik kesimpulan bahwa sistem dapat bekerja dengan baik, meskipun kualitas style browser rendah.

\subsection{Pengujian Waktu Respon Bot dengan Sistem Operasi Berbeda Jaringan Sama}

Pengujian waktu respon bot dengan sistem operasi berbeda jaringan sama dilakukan untuk mengetahui keandalan sistem operasi yang digunakan. Jaringan yang digunakan adalah $3 \mathrm{G}$ atau HSPA. Pengujian ini terhadap 3 perangkat yang berbeda, dengan menampilkan waktu antara pengguna mengirim pesan dengan bot membalasnya. Tabel 3 berikut adalah hasil pengujian respon bot dengan os berbeda jaringan sama.

Tabel 3 menunjukkan respon waktu bot dengan OS berbeda jaringan sama. Terdapat 11 fungsi yang masingmasing diuji waktu responnya. Dari Tabel 3 diatas dibuatlah grafik seperti yang ditunjukkan Gambar 6 .

Dari Gambar 6 grafik menunjukkan waktu respon bot. Rata-rata waktu respon bot dengan OS sama jaringan berbeda ditunjukkan pada kisaran waktu 4 hingga 4,9 detik. Adapun rata-rata waktu respon masing-masing smartphone adalah Oppo A37 4,05 detik, Xiaomi Redmi 3x 4,53 detik, dan Iphone 6s 4,34 detik. Dari data rata-rata waktu respon bot dapat disimpulkan bahwa OS smartphone sama tidak mempengaruhi respon bot dan bot tergolong responsif sehingga pengguna tidak perlu menunggu lama balasan dari bot.
Tabel 3. Hasil Pengujian Waktu Respon Bot dengan OS Berbeda Jaringan Sama

\begin{tabular}{|c|c|c|c|c|}
\hline \multirow{2}{*}{$\begin{array}{l}\text { Uji } \\
\text { coba }\end{array}$} & \multirow{2}{*}{$\begin{array}{c}\text { Bentuk } \\
\text { Pengujian }\end{array}$} & \multicolumn{3}{|c|}{ Hasil Pengujian } \\
\hline & & $\begin{array}{c}\text { Oppo } \\
\text { A37 }\end{array}$ & $\begin{array}{c}\text { Xiaomi } \\
\text { Redmi 3x }\end{array}$ & $\begin{array}{c}\text { Iphone } \\
6 \mathrm{~s}\end{array}$ \\
\hline 1 & $\begin{array}{l}\text { Menambahkan bot dan } \\
\text { memulai percakapan } \\
\text { dengan menekan /start }\end{array}$ & $4,9 \mathrm{~s}$ & $6,5 \mathrm{~s}$ & $6,3 \mathrm{~s}$ \\
\hline 2 & $\begin{array}{l}\text { Menampilkan keyboard } \\
\text { untuk memverifikasi nomor } \\
\text { telepon }\end{array}$ & $4,2 \mathrm{~s}$ & $4,1 \mathrm{~s}$ & $4,8 \mathrm{~s}$ \\
\hline 3 & $\begin{array}{l}\text { Mengirim nomor telepon } \\
\text { untuk mengambil chat id. }\end{array}$ & $5,4 \mathrm{~s}$ & $5 \mathrm{~s}$ & $5,5 \mathrm{~s}$ \\
\hline 4 & Mengecek saldo yang ada & $3,8 \mathrm{~s}$ & $4,4 \mathrm{~s}$ & $4,8 \mathrm{~s}$ \\
\hline 5 & $\begin{array}{l}\text { Menampilkan keyboard cek } \\
\text { transaksi }\end{array}$ & $4,3 \mathrm{~s}$ & $4,8 \mathrm{~s}$ & $3,9 \mathrm{~s}$ \\
\hline 6 & $\begin{array}{ll}\text { Melihat } & \text { laporan } \\
\text { pembayaran tol } & \end{array}$ & $3,7 \mathrm{~s}$ & $4,5 \mathrm{~s}$ & $4,5 \mathrm{~s}$ \\
\hline 7 & $\begin{array}{l}\text { Melihat laporan pembelian } \\
\text { saldo }\end{array}$ & $3,5 \mathrm{~s}$ & $4,5 \mathrm{~s}$ & $5 \mathrm{~s}$ \\
\hline 8 & $\begin{array}{l}\text { Menekan tombol "Hubungi } \\
\text { Kami" }\end{array}$ & $3,1 \mathrm{~s}$ & $3,3 \mathrm{~s}$ & $4,1 \mathrm{~s}$ \\
\hline 9 & Menekan tombol "Bantuan" & $3,5 \mathrm{~s}$ & $4,4 \mathrm{~s}$ & 4,7 \\
\hline 10 & $\begin{array}{l}\text { Menekan tombol "Kembali" } \\
\text { Mobil melewati gerbang tol, }\end{array}$ & $4,3 \mathrm{~s}$ & $4,3 \mathrm{~s}$ & $4,3 \mathrm{~s}$ \\
\hline 11 & $\begin{array}{l}\text { pengguna mendapatkan } \\
\text { notifikasi }\end{array}$ & $3,8 \mathrm{~s}$ & $4 \mathrm{~s}$ & $4,5 \mathrm{~s}$ \\
\hline
\end{tabular}

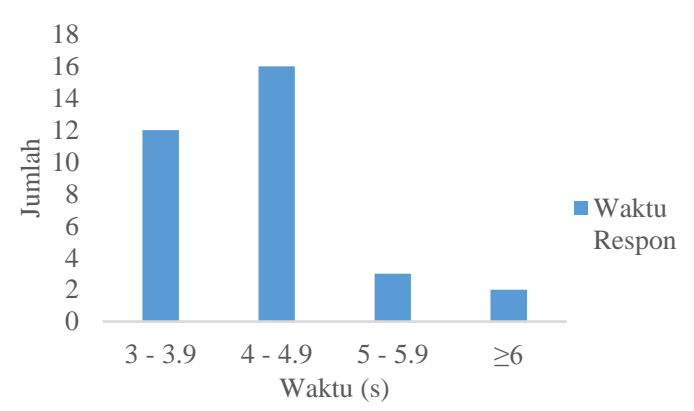

Gambar 6. Grafik Waktu Respon Bot dengan OS Berbeda Jaringan Sama

\subsection{Pengujian Waktu Respon Bot dengan Sistem Operasi Sama Jaringan Berbeda}

Pengujian waktu respon bot dengan sistem operasi sama jaringan berbeda dilakukan untuk mengetahui performa jaringan yang digunakan. Sistem operasi Android yang digunakan dalam pengujian ini adalah Lollipop pada smartphone Oppo A37. Jaringan yang digunakan dalam pengujian ini jaringan $2 \mathrm{G}, 3 \mathrm{G}$ dan $4 \mathrm{G}$. Sebelum melakukan pengujian dilukakan test ping terlebih dahulu menggunakan aplikasi Terminal Emulator yang di-install di smartphone. Server yang dituju adalah server google yaitu 8.8.8.8 dan mengambil 4 paket yang dikirim sebagai hasil . Hasil rata-rata waktu dari test ping pada jaringan $2 \mathrm{G}$ 212,5 ms, 3G 183,5 ms dan 4G 71,63 ms. Pengujian ini dilakukan terhadap 3 jaringan yang berbeda, jaringan $2 \mathrm{G}$, $3 \mathrm{G}$ dan 4G, kemudian dengan menampilkan waktu antara pengguna mengirim pesan dengan bot membalasnya. Tabel 
4 berikut adalah hasil pengujian respon bot dengan OS sama jaringan berbeda.

Tabel 4. Hasil Pengujian Waktu Respon Bot dengan OS Sama Jaringan Berbeda

\begin{tabular}{|c|c|c|c|c|}
\hline \multirow[b]{2}{*}{$\begin{array}{l}\text { Uji } \\
\text { coba }\end{array}$} & \multirow{2}{*}{$\begin{array}{l}\text { Bentuk } \\
\text { Pengujian }\end{array}$} & \multicolumn{3}{|c|}{ Hasil Pengujian } \\
\hline & & $\begin{array}{c}\text { Jaringan } \\
2 G \\
\end{array}$ & $\begin{array}{c}\text { Jaringan } \\
3 G\end{array}$ & $\begin{array}{c}\text { Jaringan } \\
4 G\end{array}$ \\
\hline 1 & $\begin{array}{l}\text { Menambahkan bot dan } \\
\text { memulai percakapan } \\
\text { dengan menekan /start }\end{array}$ & $6,9 \mathrm{~s}$ & $6,9 \mathrm{~s}$ & $4,9 \mathrm{~s}$ \\
\hline 2 & $\begin{array}{ll}\text { Menampilkan } & \\
\text { keyboard } & \text { untuk } \\
\text { memverifikasi nomor } \\
\text { telepon }\end{array}$ & $5,7 \mathrm{~s}$ & $5,7 \mathrm{~s}$ & $4,2 \mathrm{~s}$ \\
\hline 3 & $\begin{array}{l}\text { Mengirim nomor } \\
\text { telepon untuk } \\
\text { mengambil chat id. }\end{array}$ & $5,9 \mathrm{~s}$ & $5,1 \mathrm{~s}$ & $5,4 \mathrm{~s}$ \\
\hline 4 & $\begin{array}{l}\text { Mengecek saldo yang } \\
\text { ada }\end{array}$ & $4,6 \mathrm{~s}$ & $4,5 \mathrm{~s}$ & $3,8 \mathrm{~s}$ \\
\hline 5 & $\begin{array}{l}\text { Menampilkan } \\
\text { keyboard cek transaksi }\end{array}$ & $4,8 \mathrm{~s}$ & $4,8 \mathrm{~s}$ & $4,3 \mathrm{~s}$ \\
\hline 6 & $\begin{array}{l}\text { Melihat laporan } \\
\text { pembayaran tol }\end{array}$ & $5,1 \mathrm{~s}$ & $4,6 \mathrm{~s}$ & $3,7 \mathrm{~s}$ \\
\hline 7 & $\begin{array}{l}\text { Melihat laporan } \\
\text { pembelian saldo }\end{array}$ & $5,2 \mathrm{~s}$ & $4,7 \mathrm{~s}$ & $3,5 \mathrm{~s}$ \\
\hline 8 & $\begin{array}{l}\text { Menekan tombol } \\
\text { "Hubungi Kami" }\end{array}$ & $4,7 \mathrm{~s}$ & $3,7 \mathrm{~s}$ & $3,1 \mathrm{~s}$ \\
\hline 9 & $\begin{array}{l}\text { Menekan tombol } \\
\text { "Bantuan" }\end{array}$ & $4,8 \mathrm{~s}$ & $4,3 \mathrm{~s}$ & $3,5 \mathrm{~s}$ \\
\hline 10 & $\begin{array}{l}\text { Menekan tombol } \\
\text { "Kembali" }\end{array}$ & $5,1 \mathrm{~s}$ & $5,5 \mathrm{~s}$ & $4,3 \mathrm{~s}$ \\
\hline 11 & $\begin{array}{l}\text { Mobil melewati } \\
\text { gerbang tol, pengguna } \\
\text { mendapatkan notifikasi }\end{array}$ & $4,8 \mathrm{~s}$ & $4,5 \mathrm{~s}$ & $3,8 \mathrm{~s}$ \\
\hline
\end{tabular}

Tabel 4 menunjukkan respon waktu bot dengan OS sama jaringan berbeda. Terdapat 11 fungsi yang masing-masing diuji waktu responnya. Dari Tabel 4 di atas dibuatlah grafik seperti yang ditunjukkan Gambar 7.

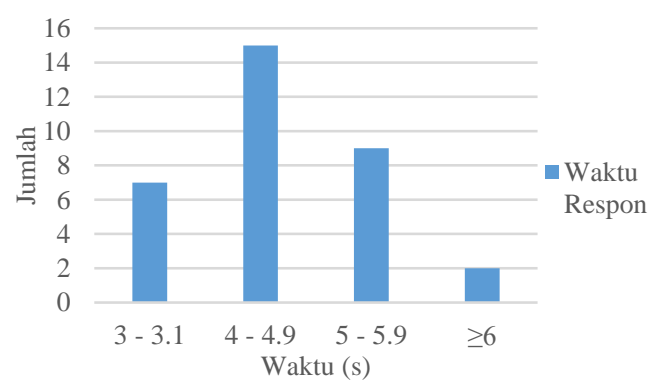

Gambar 7. Grafik Waktu Respon Bot dengan OS Sama Jaringan Berbeda

Dari Gambar 7 grafik menunjukkan waktu respon bot. Rata-rata waktu respon bot dengan OS sama jaringan berbeda ditunjukkan pada kisaran waktu 4 hingga 4,9 detik. Adapun rata-rata waktu respon masing-masing jaringan adalah jaringan $2 \mathrm{G} \mathrm{5,24} \mathrm{s}$, jaringan $3 \mathrm{G} 4,99 \mathrm{~s}$, dan jaringan 4G 4,05 s. Dari data rata-rata tersebut dapat disimpulkan bahwa waktu tercepat bot merespon ketika smartphone menggunakan jaringan $4 \mathrm{G}$ dan waktu terlambat ketika menggunakan jaringan 2G. Tetapi, secara umum bot tergolong responsif karena perbedaan waktu antar jaringan tidak begitu besar.

\subsection{Pengujian Notifikasi Pembayaran Tol}

Pengujian dilakukan dengan mendekatkan tag RFID dengan reader RFID. Tag yang digunakan menggunakan tiga tag yang sudah berisi id yang tersimpan pada database. Jarak antara tag RFID dan reader RFID sebesar kurang lebih satu meter. Data tag akan terkirim ke database dan web pada halaman laporan pembayaran tol. Pelanggan lalu akan menerima sebuah notifikasi karena tag RFID sudah terbaca oleh reader RFID. Ilustrasi saat mobil melewati gerbang tol dan reader RFID membaca tag RFID dapat dilihat pada Gambar 8. Gambar 9 merupakan data kode tag yang terdeteksi yang nantinya data-data ini akan dikirimkan ke pengguna. Gambar 10 merupakan pesan yang berisi data saat pengguna melewati gerbang tol dan pesan ini sebagai bukti pembayaran yang sah. Hasil pengujian notifikasi pembayaran tol dapat dilihat pada Tabel 5.

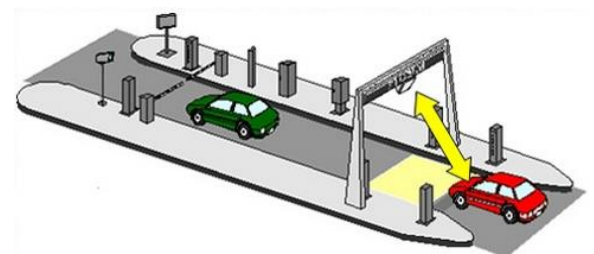

Gambar 8. Ilustrasi Mobil Melewati Gerbang Tol dengan Sistem ETC

\begin{tabular}{|l|lrrl|}
\hline no_tagrfid & nama & nama_tol & tarif & waktu_masuk \\
\hline e2960207 & Muhammad Arief Fatkhurrahman Tembalang & 4000 & $2017-09-28 ~ 20: 39: 36$ \\
\hline $86 f f e c d 5$ & Yusuf Baharuddin & Tembalang & 6000 & $2017-09-2820: 38: 45$
\end{tabular}

Gambar 9. Data Kode Tag yang Terdeteksi

\begin{tabular}{|c|c|}
\hline M $\begin{array}{l}\text { MyGTC } \\
\text { bot }\end{array}$ & $\vdots$ \\
\hline $\begin{array}{l}\text { Anda telah memasuki gerbang tol } \\
\text { Tembalang dengan biaya Rp 6,000 } \\
\text { pada } 28 \text { September } 2017 \text { 20:38:45 } 20: 33\end{array}$ & \\
\hline
\end{tabular}

Gambar 10. Pesan ketika Pengendara Melewati Gerbang Tol

Tabel 5. Hasil Pengujian Notifikasi Bot Telegram

\begin{tabular}{clccc}
\hline No & Nama Pelanggan & Kode Tag & Kode Terbaca & Notifikasi \\
\hline 1 & Yusuf Baharuddin & $86 f f e c d 5$ & $86 f f e c d 5$ & Diterima \\
2 & M arief F & e2960207 & e2960207 & Diterima \\
3 & Fuad Ashabus & e2f36e85 & e2f36e85 & Diterima \\
4 & Arisla Choiruddin & $5 \mathrm{e} 29273 \mathrm{~b}$ & $5 \mathrm{e} 29273 \mathrm{~b}$ & Diterima \\
5 & Rafi dhega & $864 \mathrm{ab2d5}$ & $864 \mathrm{ab} 2 \mathrm{~d} 5$ & Diterima \\
\hline
\end{tabular}

Tabel 5 menunjukkan bahwa data identifikasi kendaraan dan notifikasi pembayaran telah berjalan dengan baik. Tabel ini menunjukkan ID tag dan ID terbaca dengan 
benar dan sesuai dengan database. Notifikasi pembayaran juga telah diterima oleh pelanggan yang melewati reader RFID.

\section{Kesimpulan}

Setelah dilakukan pengujian terhadap sistem secara keseluruhan diketahui bahwa sistem sudah dapat bekerja dengan baik, terutama terhadap fungsi-fungsi baik di web maupun bot dan notifikasi pembayaran. Dapat dilihat pada Tabel 1, Tabel 2, Tabel 3, Tabel 4, dan Tabel 5. Sistem operasi pada smartphone tidak mempengaruhi pada kinerja bot karena waktu responnya tidak menunjukkan perbedaan yang cukup signifikan. Begitu pula pada jaringan yang digunakan pada smartphone baik $2 \mathrm{G}, 3 \mathrm{G}$ dan $4 \mathrm{G}$ tidak mempengaruhi pada kinerja bot. Karena selisih waktu respon antar jaringan sekitar 1 detik saja. Akan tetapi, jaringan yang bagus untuk digunakan adalah $4 \mathrm{G}$ dengan rata-rata waktu 4,05 detik. Notifikasi pembayaran juga berhasil dikirimkan setelah reader RFID membaca tag RFID. Sistem ini masih memiliki kekurangan, dan masih dapat dikembangkan lagi. Pertama, 1 membuat fungsi membeli saldo melalui bot Telegram sehingga pengguna atau pelanggan sistem ETC tidak perlu ke bank atau mitra terkait untuk membeli saldo. Kedua, sistem dilengkapi GIS (Geographic Information System) baik di sisi server (web) maupun pada bot. Salah satu tujuannya apabila pengguna atau pelanggan mengalami mogok atau masalah saat berada di jalan tol sehingga mudah dalam mengetahui lokasinya. Ketiga, keamanan sistem terutama pada keamanan jaringan. Karena sistem yang dibuat berbasis web service.

\section{Referensi}

[1] Sodikin, B. Riyanto dan B. Pudjianto, "Kajian Masalah Antrian Pada Sistem Pengumpulan Tol Konvensional Terhadap Rancangan Sistem Pengumpulan Tol Elektronik," Universitas Diponegoro, Semarang, 2005.

[2] Amol A. Chapate; D. D. Nawgaje, "Electronic Toll Collection System Based on ARM". International Journal of Science, Engineering and Technology Research (USETR)," vol. 4, no. 1, January 2015.

[3] K. Persad, C. M. Walton dan S. Hussain, "Toll Collection Technology and Best Practices," Center for Transportation Research The University of Texas at Austin, Austin, Texas, 2006.

[4] R.-C. Jou, Y.-C. Chiou, C.-W. Kuo dan H.-I. Tan, "Freeway drivers' willingness to pay for an on board unit under," ELSEVIER, no. 27, pp. 16-24, 2013.

[5] V. V. Kommineni , K. R. Kumar dan W. J. Joseph, "INTEGRATED HIGHWAY MANAGEMENT SYSTEM USING RADIO FREQUENCY TECHNOLOGY BASED ON ARM," IJERA, vol. 2, no. 3, pp. 151-155, 2012.

[6] D.-P. Pop dan A. Altar, "Designing an MVC Model for Rapid Web Application Development," ELSEVIER, vol. 69, p. 1172 - 1179, 2014.

[7] A. Y. Aleryani, "Comparative Study between Data Flow Diagram and Use," IJSP, vol. 6, no. 3, pp. 124127, 2016. 